\title{
Contributions of primary organic matter sources to macroinvertebrate production in an intertidal salt marsh (Scirpus triqueter) ecosystem
}

\author{
Chang-Keun Kang ${ }^{1, *}$, Eun Jung Choy ${ }^{1}$, Sang-Kyu Paik ${ }^{2}$, Hyun Je Park ${ }^{1}$, \\ Kun-Seop Lee ${ }^{1}$, Soonmo ${ }^{3}{ }^{3}$

\begin{abstract}
${ }^{1}$ Department of Biology, and ${ }^{3}$ Department of Marine Science, Pusan National University, Busan 609-735, South Korea
${ }^{2}$ Marine Environment Research Department, Korea Ocean Research and Development Institute, Ansan 425-600, South Korea
\end{abstract}

\begin{abstract}
The trophic importance of different primary organic matter sources to macroinvertebrates was studied in the intertidal salt marsh (Scirpus triqueter) habitat of the Nakdong River estuary (Korea) using carbon and nitrogen stable isotope ratios. $\delta^{13} \mathrm{C}$ and $\delta^{15} \mathrm{~N}$ values of primary producers and dominant invertebrates, along with their biomass or abundance, were monitored monthly from December 2004 to November 2005. S. triqueter flourished from spring to summer and vanished in late fall to winter. Biomass of microphytobenthos peaked in late spring to summer. Of 25 taxa of macrozoobenthos collected, 7 were found throughout the year. Despite a dramatic seasonal fluctuation in the marsh club-rush $S$. triqueter biomass, the expected seasonal change in the isotopic signatures of the 7 dominant macroinvertebrates was not found. A large gap (3.5 to $12.3 \%$ ) in the $\delta^{13} \mathrm{C}$ signature between $S$. triqueter $(-27.9 \pm 1.0 \%$ ) and the marsh-dwelling macroinvertebrates (means from -24.4 to $-15.6 \%$ ) indicates little utilization of this marsh-derived organic matter by the animals. Surface grazers and deposit feeders (e.g. Hediste japonica, Heteromastus filiformis, Angustassiminea castanea, Ilyoplax pusilla and Paranthura sp.) had $\delta^{13} \mathrm{C}$ similar to $\delta^{15} \mathrm{~N}$ and about $4 \%$ higher than those $(-16.5 \pm 2.1$ and $8.7 \pm 1.1 \%$, respectively) of microphytobenthos, revealing that mainly microphytobenthos-derived carbon contributed to their diets. Two suspension-feeding bivalves (e.g. Laternula marilina and Corbicula sp.) showed a similar $\delta^{13} \mathrm{C}$ to that of suspended particulate organic matter $(\mathrm{POM})$ in the channel $(-23.0 \pm 0.7 \%$ o) and the Nakdong River $(-24.5 \pm 1.9 \%)$. However, their $\delta^{15} \mathrm{~N}$ values are about $4 \%$ higher than that of channel POM $(5.7 \pm 0.6 \%$ ), but lower compared to that of river POM $(-11.6 \pm 2.3 \%$ ), suggesting that organic matter derived from coastal phytoplankton, not river discharge, is a major nutritional source for these bivalves. Overall, our isotopic data suggest that the $S$. triqueter-marsh invertebrates are generally more dependent on organic matter derived from algal sources than on $S$. triqueter or terrestrial sources.
\end{abstract}

KEY WORDS: Scirpus triqueter - Salt marsh - Stable isotopes · Food source - Macroinvertebrate · Microphytobenthos

\section{INTRODUCTION}

Intertidal salt marshes in estuarine systems are among the most productive ecosystems in the world. Much attention has been paid to the role of marsh vascular plants, i.e. as a food source for estuarine and offshore consumers, a habitat for estuarine organisms and a regulator of estuarine chemical cycles. However, their trophic role in supporting marsh/estuary food webs has been an ongoing subject of debate for several decades. Many reviews have addressed the importance of organic detritus, derived mainly from marsh vascular plants, as a food source for estuarine consumers (Nixon 1980, Mann 1982). This idea was first 
examined by gut analysis of lower-level consumers (Darnell 1961). A number of early studies concluded that much of the organic detritus from salt marshes is used by marsh consumers and is transported out of the estuary to coastal regions (Teal 1962, Odum 1980). However, with the help of natural stable isotope techniques, subsequent research demonstrated that algae, such as benthic diatoms and phytoplankton, not marsh detritus, are the major source of organic matter supporting consumer production in salt marshes (Haines 1976, Sullivan \& Moncreiff 1990, Page 1997). On the other hand, recent studies using multiple stable isotopes showed that marsh detritus and phytoplankton are equally important to marsh and estuarine consumers (Peterson \& Howard 1987, Currin et al. 1995). The conflicting results of these studies show large gaps in the understanding of estuarine ecologists concerning the trophic role of marsh plants and indicate that marsh systems are very complex.

Numerous studies into the role of salt marsh plants in the functioning of coastal systems have been conducted in salt marshes along North American Atlantic coasts dominated by Spartina alterniflora Loisel. The relative importance of primary production sources ultimately supporting marsh consumers vary with respect to the type of marsh macrophyte vegetation (Wainright et al. 2000). Tidal regime can also be an important factor in determining the trophic role of salt marsh plants (Deegan \& Garritt 1997). For example, salt marshes in most European estuaries are confined to the uppermost part of the intertidal zone, where they are immersed only periodically by spring tides, whereas the North American marshes are immersed twice a day (see Créach et al. 1997). The trophic role of salt marshes is still difficult to compare between these 2 systems, because of the different vegetation composition and flooding regime.

Here we address important components of primary producers that are utilized by macrozoobenthic consumers in a Korean Scirpus triqueter L. marsh ecosystem, where, as in the North America, the marshes are inundated twice a day. This marsh area is used as a habitat for wintering of migratory waterfowl, such as swans, geese and ducks, at the Nakdong River estuary (Kim 2006). Growth of $S$. triqueter occurs from April to September. This vascular hydrophyte forms a tuber, which accounts for 44 to $57 \%$ of total biomass 10 to $30 \mathrm{~cm}$ below ground, from September to October. The tubers are utilized by the migrating waterfowl as winter food. After the arrival of waterfowl in mid-October, the tubers and total biomass of $S$. triqueter rapidly decrease. Only about $10 \%$ of the tubers exist in midDecember, so the waterfowl emigrate from the estuary due to the lack of food resources. As a result of this type of top-down control by the seasonal stopover of migrating waterfowl, as well as a fall to winter decline in biomass of triangular club-rush, the marsh bed remains an almost plant-free mudflat during the winter to early spring period. In the present study, we monitored the macrozoobenthos community, stable carbon and nitrogen isotope ratios of dominant macroconsumers and major potential organic matter sources for a year to test whether the trophic base of the marsh food web depends on the conspicuous seasonal variation in biomass of $S$. triqueter.

Sources of carbon and nitrogen used for consumer production in aquatic ecosystems are now commonly identified using stable $\mathrm{C}$ and $\mathrm{N}$ isotope analyses (Fry \& Sherr 1984, Michener \& Shell 1994). This approach is based on the assumption that stable $\mathrm{C}$ and $\mathrm{N}$ isotope ratios $\left(\delta^{13} \mathrm{C}\right.$ and $\left.\delta^{15} \mathrm{~N}\right)$ comprising the tissue of consumers reflects their food sources. When there is sufficient discrimination among different primary producers, isotope ratios of consumers indicate which food source is actually being used for tissue production. Biological fractionation between the isotopic ratios of the food source and that of the consumers appears to be small or negligible in ${ }^{13} \mathrm{C}(<1 \%$; Fry \& Sherr 1984), but more apparent in ${ }^{15} \mathrm{~N}$ (on average $3.4 \pm 1.1 \%$; Minagawa \& Wada 1984, Owens 1987). Because of this difference, $\delta^{13} \mathrm{C}$ is usually used to identify the food source, while $\delta^{15} \mathrm{~N}$ is used to identify the trophic level. When there is an ambiguity among isotopic values of contrasting food sources, isotopic signatures sometimes provide poor resolution. $\delta^{15} \mathrm{~N}$ is also useful in identifying the general pathways of organic matter through aquatic food webs, because values in consumers reflect those of their food, after accounting for 2 to $4 \%$ enrichment due to trophic fractionation (Peterson \& Fry 1987).

\section{MATERIALS AND METHODS}

Study site. The study was conducted at a Scirpus triqueter bed of the intertidal flats in the Nakdong River estuary, Korea (Fig. 1). The estuary has a welldeveloped delta and is protected by sand dunes parallel to the coastal line. It has undergone significant change in its environmental conditions since the construction of the Nakdong River Barrier in 1987 (Jang \& Kim 2006). Although $15.5 \mathrm{~km}^{2}$ of the mudflat area has been reclaimed since dam construction, physical alteration of the estuary has resulted in an expansion of sand dunes and intertidal beds. Along with the expanded intertidal bed (about $40 \mathrm{~km}^{2}$ ), there has been a dramatic change in the dominant macrophyte vegetation over the past $20 \mathrm{yr}$ (Kim 2006). For example, a Zostera marina bed, which covered about $13 \mathrm{~km}^{2}$ of the estuary, vanished, and only small patches of about 


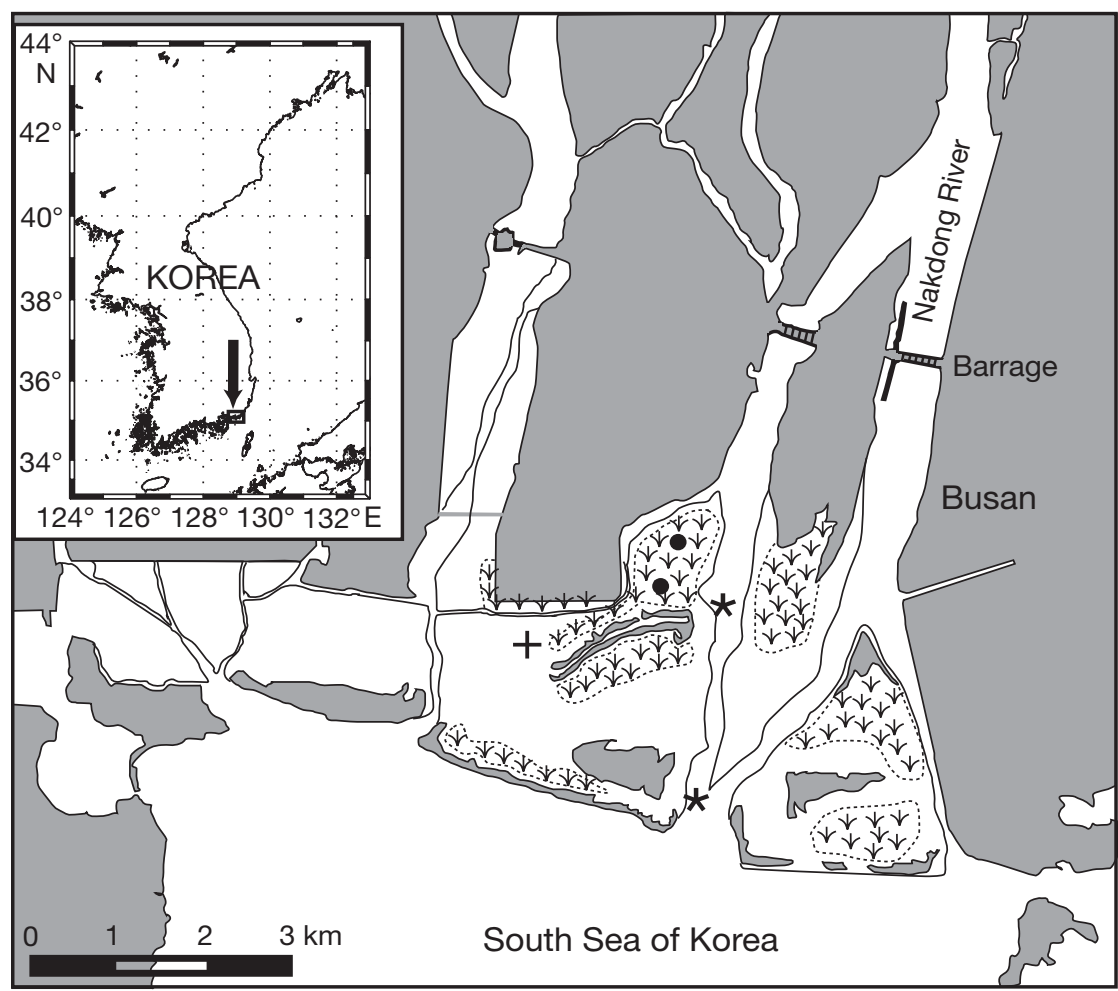

Fig. 1. Location of the study area in the Nakdong River estuary. Patterned areas indicate Scirpus triqueter-covered area. Solid line indicates low water line of tidal flats. ๑: study sites for $S$. triqueter bed; $*$ : sites for channel particulate organic matter; +: site for microphytobenthos on bare tidal flat

surface of the marsh bed and dominated by Navicula spp., Amphora coffeaeformis (C. A. Agardh) Kützing and Caloneis spp. (our data). Commercial clams (mainly Corbicula sp.) are cultured intensively on the tidal flats near the marsh boundary.

Sample collection. Scirpus triqueter, macroalgae, microphytobenthos, surface sediments and benthic macroinvertebrates were collected at monthly intervals from December 2004 to November 2005. Of these, the macroalgae Enteromorpha compressa were collected in May and June 2005. Two sites were chosen within a marsh system (Fig. 1), the sediments of which consisted of muddy sand (sand $>80 \%$ ). A sampling site for suspended particulate organic matter of river water (river POM) and riparian vegetation was located approximately $10 \mathrm{~km}$ upstream of the Nakdong River Barrier. Channel POM was collected at 2 main channel sites during flood tides, to ensure the sampling of incoming estuarine water.

Density and biomass of Scirpus triqueter were monitored from October 2004 to December 2005. At each sampling site, 3 replicate samples were

$0.6 \mathrm{~km}^{2}$ remain. Phragmites australis (Cav.) Trin. ex Steud., which was the most dominant vegetation in the estuary (covering ca. $11 \mathrm{~km}^{2}$ ), now covers about $1 \mathrm{~km}^{2}$ of the upper part of the intertidal flats. Currently, the most dominant vascular vegetation is $S$. triqueter, which covers about $5.2 \mathrm{~km}^{2}$ of the intertidal flats (present study). The tidal marsh is regularly flooded twice a day, with a maximum tidal amplitude of $1.7 \mathrm{~m}$ during spring tides. While mixing and circulation processes in the estuary were dominated by tidal currents prior to dam construction, these processes were greatly altered by the artificial control of the fresh river water discharge after its construction (Jang \& Kim 2006). River runoff volume is highly variable according to the opening and closing of the floodgate of the barrage, but maximum discharge coincides with the summer monsoon. Freshwater runoff causes a drastic decrease in salinity, excess nutrient input and increase in suspended matter, which results in changes in phytoplankton composition and a large decrease in primary productivity of phytoplankton in the estuarine area (Yang et al. 2001). Oceanic waters enter the tidal flat and marsh through the southern entrance between sand dunes. Benthic microalgal mats are commonly visible on the collected to $50 \mathrm{~cm}$ depth of sediment (maximum depth of generation of tubers) using a $0.5 \mathrm{~m}$ quadrate. After returning to the laboratory, shoots were counted. Each organ was separated, carefully cleaned and dried at $60^{\circ} \mathrm{C}$ for $72 \mathrm{~h}$, and the above- and below-ground biomasses were measured. A series of pooled samples of the separate parts was also prepared to analyze the isotopic composition. Macroalgae, where present, and riparian vegetation were collected by hand and carefully cleaned to remove epibionts.

Microphytobenthos were sampled by scraping the visible mats of benthic diatoms on the sediment surface at a marsh site and a neighboring intertidal flat site. A pure sample of benthic diatoms was separated through a procedure slightly modified from the technique of Couch (1989). A more detailed description of the procedure for the extraction of microphytobenthos is given elsewhere (Riera et al. 1999, Wainright et al. 2000). Microphytobenthos biomass was estimated by analyzing surface sediments (the top $5 \mathrm{~mm}$ ) for chlorophyll $\mathrm{a}$ (chl a) using high-performance liquid chromatography (HPLC). Five replicate cores were collected at each sampling location at low tide. Samples were stored on ice and kept in the dark until being returned to the lab- 
oratory, where they were frozen. Freeze-dried sediment samples were weighed (approximately $1 \mathrm{~g}$ ) and then were extracted with $100 \%$ acetone $(10 \mathrm{ml})$ for $24 \mathrm{~h}$ in the dark $\left(-20^{\circ} \mathrm{C}\right)$, sonicated for $5 \mathrm{~min}$ and centrifuged at $3000 \mathrm{rpm}(3293 \times g)$ for $15 \mathrm{~min}$. The extracts were then filtered through a $0.20 \mu \mathrm{m}$ Teflon filter and put in an autosampler. The subsequent HPLC techniques are described elsewhere (Kang et al. 2006). Freeze-dried sediments from the core samples were acidified with $1 \mathrm{~N} \mathrm{HCl}$ until bubbling stopped, to remove carbonates; they were then dried at $60^{\circ} \mathrm{C}$ for $72 \mathrm{~h}$ without rinsing and ground again in order to determine the isotopic composition of the first centimeter of sedimentary organic matter (SOM).

Benthic macroinvertebrates for isotope analysis were collected by hand or by sieving of sediments from a rectangular can corer $\left(0.025 \mathrm{~m}^{2}\right)$. Invertebrates were kept alive overnight at the laboratory in filtered water from the sampling site to evacuate gut contents. Only muscle tissues of live and intact organisms were collected, to minimize contamination with other material, and were frozen immediately.

River and channel POM for isotopic analysis were collected by filtering a known volume (about 20 l) of water, which was prefiltered through a $100 \mu \mathrm{m}$ sieve, to remove large particles and zooplankton, onto prewashed and precombusted $\left(450^{\circ} \mathrm{C}\right.$ for $\left.4 \mathrm{~h}\right)$ Whatman GF/F filters $(0.70 \mu \mathrm{m}$ nominal pore size). The POM samples were acid soaked with several drops of $1 \mathrm{~N}$ $\mathrm{HCl}$, rinsed with distilled water and then kept frozen until later analysis. All POM, floral and faunal samples were freeze dried and ground into a fine powder with a mortar and pestle.

Stable isotope analysis. The carbon and nitrogen isotopic compositions of the powdered samples were determined using a continuous-flow isotope ratio mass spectrometer (CF-IRMS, Micromass Isoprime) coupled with an elemental analyzer (Eurovector 3000 Series). For isotope analysis, 0.5 to $1.5 \mathrm{~g}$ of samples were transferred into small tin capsules. Samples wrapped in tin capsules were oxidized at high temperature $\left(1030^{\circ} \mathrm{C}\right)$ in the elemental analyzer. Stable isotope data for the resultant $\mathrm{CO}_{2}$ and $\mathrm{N}_{2}$ were expressed as the relative difference between ratios of the sample and conventional standard gases (Pee Dee Belemnite, PDB, for carbon and atmospheric $\mathrm{N}_{2}$ for nitrogen). Delta $(\delta)$ notation is used to express these relative differences:

$$
\delta X(\%)=\left[\left(R_{\text {sample }} / R_{\text {standard }}\right)-1\right] \times 10^{3}
$$

where $X$ is ${ }^{13} \mathrm{C}$ or ${ }^{15} \mathrm{~N}$ and $R$ is the ${ }^{13} \mathrm{C} /{ }^{12} \mathrm{C}$ or ${ }^{15} \mathrm{~N} /{ }^{14} \mathrm{~N}$. A secondary standard of known relation to the international standard was used as a reference material. Analytical precision was approximately 0.1 and $0.2 \%$ for $\delta^{13} \mathrm{C}$ and $\delta^{15} \mathrm{~N}$, respectively. All statistical analyses were performed using SPSS software. Because all the data did not significantly deviate from a normal distribution (Shapiro-Wilk test, $\mathrm{p}<0.05$ ), no prior transformation of the data was performed. Multivariate analysis of variance (MANOVA) was used within the framework of a general linear model to test for differences in dual isotope signatures $\left(\delta^{13} \mathrm{C}\right.$ and $\left.\delta^{15} \mathrm{~N}\right)$ among all species within food source groupings and functional feeding groups of consumers. Wilk's lambda was used to evaluate the results. Where there was a significant difference $(p<0.05)$ among mean vectors of variables, 1 -way ANOVA was used to make overall comparisons of individual variables among species groupings, and subsequent pair-wise comparisons were conducted with Tukey's HSD (honestly significant differences) test.

\section{RESULTS}

\section{Seasonal dynamics of Scirpus triqueter stock and microphytobenthos biomass}

During a monitoring period of $15 \mathrm{mo}$, shoot growth of Scirpus triqueter was initiated in May 2005 (Fig. 2). It was followed by rapid growth during early summer (June to July). The highest shoot density was observed with a mean of approximately 800 shoots $\mathrm{m}^{-2}$ during summer (August and September). Biomass of $S$. tri-
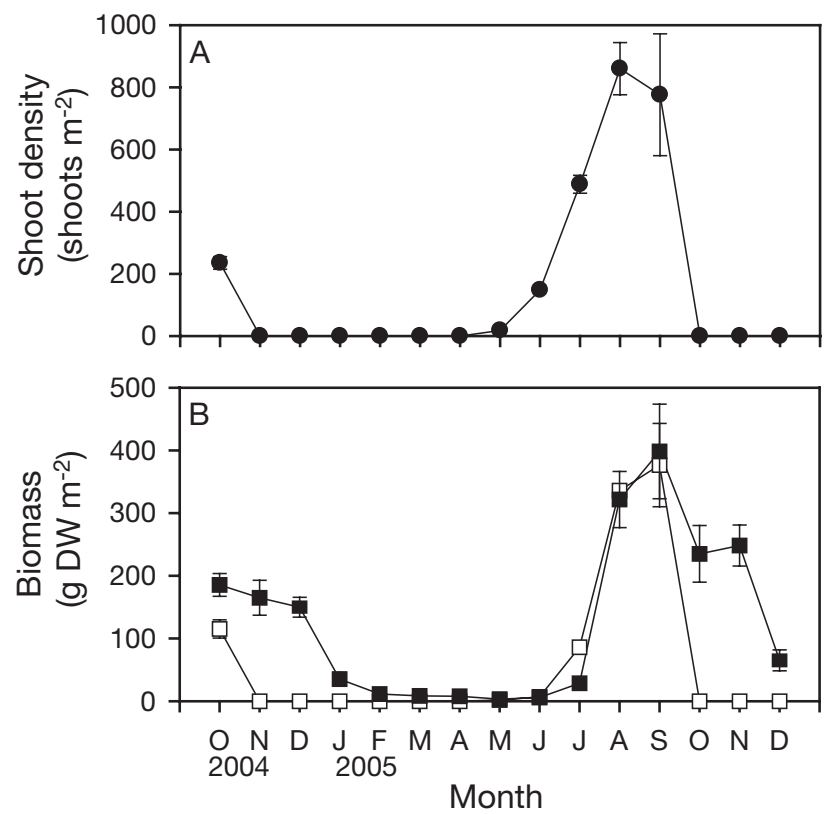

Fig. 2. Scirpus triqueter. Monthly variation in (A) shoot density and (B) biomasses ( $\square$ : above ground; $\square$ : below ground) in the Nakdong River estuary. Data represent a mean $( \pm 1 \mathrm{SD})$ of 6 replicates at 2 sampling sites ( 3 replicate samples at each site) because the $S$. triqueter biomass values were not significantly different between sites. DW: dry weight 


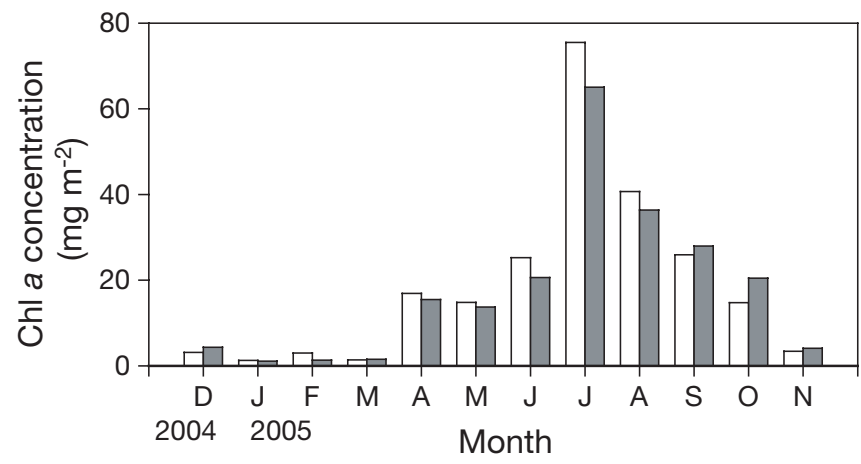

Fig. 3. Monthly variation of chlorophyll a concentration in surface sediments in the Nakdong River estuary (white bar: Scirpus triqueter bed; black bar: adjacent bare tidal flat). Data represent a mean of 5 replicate cores

queter varied dramatically with season (Fig. 2). Both the above- and below-ground biomasses sharply increased from spring and peaked in summer (August and September). The above-ground tissues were entirely absent from November 2004 to April 2005. In $2005, S$. triqueter shoots were not observed from October. The below-ground biomass dropped sharply after October in the monitoring period.

$\mathrm{Chl}$ a contents in the top $5 \mathrm{~mm}$ of the sediments varied from 1.3 to $75.5 \mathrm{mg} \mathrm{chl} \mathrm{a} \mathrm{m} \mathrm{m}^{-2}$ (annual mean $=18.8 \pm$ 21.7 ) and from 1.1 to $65.1 \mathrm{mg} \mathrm{chl} \mathrm{a} \mathrm{m}{ }^{-2}$ (annual mean = $17.7 \pm 18.8$ ) at a marsh site and a neighboring intertidal flat site, respectively (Fig. 3). There was no significant difference in sediment chl a content between the sites (paired $t$-test, $\mathrm{df}=11, \mathrm{p}=0.338$ ). A significant increase in sediment chl a content was encountered in summer from June to September at both sites (Tukey's HSDtest, $\mathrm{p}<0.05)$.

\section{Macrozoobenthic community}

Twenty-five taxa were collected at the marsh (Scirpus triqueter) bed of the Nakdong River estuary throughout the sampling period (Table 1). The species composition was very similar at both stations. Seven taxa were found almost throughout the study period of 12 mo (Table 2). Two polychaetous taxa, Heteromastus filiformis (Claparede) and Hediste japonica (Izuka, 1908), dominated the macrobenthic assemblage, showing a cumulative mean monthly dominance of 71.8 and $74.9 \%$ at Sites A and B, respectively. $H$. japonica was mainly found from May to October, when $S$. triqueter grew thickly. The gastropod Angustassiminea castanea (Westerlund, 1883) showed a remarkable mean monthly dominance, being constant at both sites. The bivalves Laternula marilina (Reeve, 1863) and Corbicula sp., despite a low mean monthly
Table 1. Taxa of macrozoobenthic assemblages collected from the Scirpus triqueter bed (Sites A and B), and mean monthly values of the number of individuals per square meter $(\mathrm{N})$ and dominance $(\mathrm{D}, \%)$ of each species during the sampling period

\begin{tabular}{|c|c|c|c|c|}
\hline \multirow[t]{2}{*}{ Taxon } & \multicolumn{2}{|c|}{ Site A } & \multicolumn{2}{|c|}{ Site B } \\
\hline & $\mathrm{N}$ & $\mathrm{D}$ & $\mathrm{N}$ & $\mathrm{D}$ \\
\hline \multicolumn{5}{|l|}{ Polychaeta } \\
\hline Tylorrhynchus heterochaetus & 15 & 0.8 & 11 & 0.8 \\
\hline Hediste japonica & 399 & 17.9 & 416 & 19.9 \\
\hline Prionospio cirrifera & 73 & 4.6 & 5 & 0.7 \\
\hline Eteone sp. & 33 & 2.1 & 17 & 1.2 \\
\hline Heteromastus filiformis & 673 & 53.9 & 668 & 55.0 \\
\hline Pseudopotamilla occelata & 5 & 0.5 & 1 & 0.0 \\
\hline \multicolumn{5}{|l|}{ Nemertinea } \\
\hline Nemertea unid. & 6 & 0.5 & 3 & 0.1 \\
\hline \multicolumn{5}{|l|}{ Mollusca } \\
\hline Laternula marilina & 74 & 3.3 & 50 & 2.9 \\
\hline Corbicula sp. & 28 & 1.4 & 18 & 1.3 \\
\hline Moerella rutila & 1 & 0.0 & 0 & 0.0 \\
\hline Myadora sp. & 0 & 0.0 & 2 & 0.1 \\
\hline Angustassiminea castanea & 58 & 4.0 & 57 & 6.4 \\
\hline Cryptonatica sp. & 81 & 5.7 & 68 & 5.8 \\
\hline \multicolumn{5}{|l|}{ Crustacea } \\
\hline Cumacea unid. & 1 & 0.1 & 1 & 0.1 \\
\hline Ilyoplx pusilla & 14 & 1.0 & 8 & 0.4 \\
\hline Scopimera globosa & 8 & 0.5 & 0 & 0.0 \\
\hline Tanaidacea unid. & 2 & 0.2 & 1 & 0.1 \\
\hline Paranthura sp. & 11 & 0.6 & 6 & 0.5 \\
\hline Gammaridea unid. 1 & 1 & 0.1 & 2 & 0.2 \\
\hline Gammaridea unid. 2 & 1 & 0.1 & 2 & 0.1 \\
\hline Decapoda larvae & 1 & 0.1 & 0 & 0.0 \\
\hline \multicolumn{5}{|l|}{ Insecta } \\
\hline Insecta unid. 1 & 25 & 1.8 & 35 & 3.1 \\
\hline Insecta unid. 2 & 4 & 0.2 & 8 & 0.4 \\
\hline Insecta unid. 3 & 3 & 0.3 & 0 & 0.0 \\
\hline Insecta unid. 4 & 7 & 0.3 & 5 & 0.5 \\
\hline Total & 1524 & & 1384 & \\
\hline
\end{tabular}

dominance, were consistently found. A density peak of L. marilina was recorded from June to September. The crab Ilyoplax pusilla (De Haan,1835) and the isopod Paranthura sp. were less frequently collected, having a very low mean monthly dominance.

\section{Isotopic signatures of potential food sources}

Although the $\delta^{13} \mathrm{C}$ signatures of potential food sources exhibited considerable seasonal variations, their ranges were distinct (Fig. 4). Dual isotope analysis showed significant differences among the potential food sources (MANOVA, p $<0.001$, Fig. 5). Marsh vascular plant Scirpus triqueter had the lowest $\delta^{13} \mathrm{C}$ values, ranging from -29.2 to $-26.3 \%$, with a mean of $-27.9 \pm 1.0 \%$. This was comparable with a mean $( \pm \mathrm{SD})$ of $-28.0 \pm 1.8 \%$ for riparian vegetation of the Nakdong River. However, a significant difference between these 
Table 2. Monthly variation in the number of individuals per square meter of dominant species of macrozoobenthos collected from 2 sites (A and B) during the sampling period. po: polychaete; bi: bivalve; ga: gastropod; cr: crab; is: isopod

\begin{tabular}{|c|c|c|c|c|c|c|c|c|c|c|c|c|}
\hline \multirow{2}{*}{ Species } & \multirow{2}{*}{$\begin{array}{c}2004 \\
\text { Dec }\end{array}$} & \multirow[b]{2}{*}{ Jan } & \multirow[b]{2}{*}{ Feb } & \multirow[b]{2}{*}{ Mar } & \multirow[b]{2}{*}{ Apr } & \multirow[b]{2}{*}{ May } & -2005 & \multirow[b]{2}{*}{ Jul } & \multirow[b]{2}{*}{ Aug } & \multirow[b]{2}{*}{ Sep } & \multirow[b]{2}{*}{ Oct } & \multirow[b]{2}{*}{ Nov } \\
\hline & & & & & & & Jun & & & & & \\
\hline \multicolumn{13}{|l|}{ Site A } \\
\hline Hediste japonica (po) & 0 & 5 & 5 & 0 & 0 & 185 & 1750 & 890 & 550 & 1135 & 255 & 15 \\
\hline Heteromastus filiformis (po) & 650 & 880 & 685 & 1065 & 775 & 395 & 785 & 435 & 750 & 350 & 575 & 730 \\
\hline Laternula marilina (bi) & 0 & 0 & 15 & 10 & 15 & 10 & 85 & 265 & 140 & 340 & 10 & 0 \\
\hline Corbicula sp. (bi) & 9 & 6 & 15 & 6 & 9 & 5 & 5 & 145 & 0 & 105 & 5 & 25 \\
\hline Angustassiminea castanea (ga) & 30 & 55 & 40 & 20 & 20 & 10 & 25 & 125 & 75 & 110 & 85 & 95 \\
\hline Ilyoplax pusilla $(\mathrm{cr})$ & 0 & 0 & 20 & 0 & 0 & 5 & 10 & 0 & 15 & 10 & 5 & 100 \\
\hline Paranthura sp. (is) & 0 & 0 & 5 & 0 & 0 & 5 & 0 & 55 & 0 & 50 & 0 & 20 \\
\hline \multicolumn{13}{|l|}{ Site B } \\
\hline Hediste japonica (po) & 30 & 25 & 5 & 5 & 30 & 20 & 1995 & 1260 & 1010 & 75 & 520 & 20 \\
\hline Heteromastus filiformis (po) & 345 & 1580 & 1170 & 350 & 1045 & 950 & 785 & 575 & 260 & 395 & 320 & 235 \\
\hline Laternula marilina (bi) & 0 & 3 & 12 & 5 & 10 & 10 & 105 & 125 & 230 & 100 & 5 & 0 \\
\hline Corbicula sp. (bi) & 0 & 5 & 4 & 4 & 5 & 3 & 5 & 5 & 70 & 5 & 102 & 7 \\
\hline Angustassiminea castanea (ga) & 90 & 55 & 25 & 110 & 20 & 20 & 5 & 130 & 95 & 35 & 45 & 55 \\
\hline Ilyoplax pusilla (cr) & 0 & 2 & 5 & 0 & 10 & 0 & 52 & 0 & 15 & 5 & 5 & 0 \\
\hline Paranthura sp. (is) & 0 & 0 & 0 & 0 & 5 & 5 & 0 & 5 & 0 & 0 & 60 & 0 \\
\hline
\end{tabular}

vascular plants was found in their $\delta^{15} \mathrm{~N}$ signatures, with means of $10.6 \pm 0.6$ and $5.9 \pm 1.5 \%$, respectively (Tukey's HSD-test, $\mathrm{p}<0.05$ ). No significant differences in either isotope between the $S$. triqueter shoot, tube tissues and detritus were found. The $\delta^{13} \mathrm{C}$ values of $S$. triqueter in this study were similar to those found in Apalachicola Bay, Florida (Chanton \& Lewis 2002).

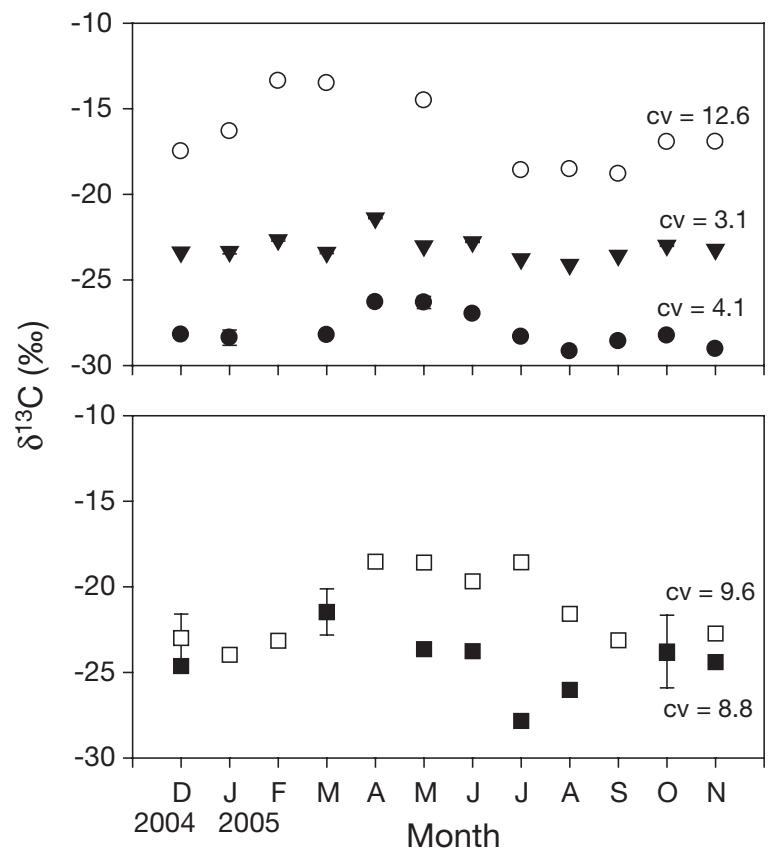

Fig. 4. Monthly variation of $\delta^{13} \mathrm{C}$ values of microphytobenthos $(\mathrm{O})$, Scirpus triqueter $(\mathbf{\bullet})$, surface sediment $(\mathbf{\nabla})$, suspended particulate organic matter (POM) in the channel ( $\square$ ) and river POM ( $(\mathbf{\square})$. Coefficients of variation $(\mathrm{cv})=\mathrm{SD} /$ mean $\times 100$. Data represent mean $\pm \mathrm{SD}$ of 3 replicate samples
The $\delta^{13} \mathrm{C}$ values of river POM varied between -27.8 and $-21.5 \%$, with a mean of $-24.5 \pm 1.9 \%$, while $\delta^{15} \mathrm{~N}$ values ranged from 7.9 to $13.8 \%$, with a mean of $11.6 \pm$ $2.3 \%$ (Fig. 5). These values were within ranges previously reported in neighboring geographical regions (Yokoyama \& Ishihi 2003, Doi et al. 2005, Kang et al. 2006). Channel POM introduced into the marsh tidal flat had a $\delta^{13} \mathrm{C}$ range from -24.1 to $-21.4 \%$, with a mean of $-23.0 \pm 0.7 \%$, and the lowest $\delta^{15} \mathrm{~N}$ signatures were between 5.0 and $7.0 \%$, with a mean of $5.7 \pm$ $0.6 \%$. The $\delta^{13} \mathrm{C}$ range of channel POM was similar to that of river POM, but $\delta^{15} \mathrm{~N}$ values readily separated estuarine from river POM (Tukey's HSD-test, $\mathrm{p}<0.05$ ).

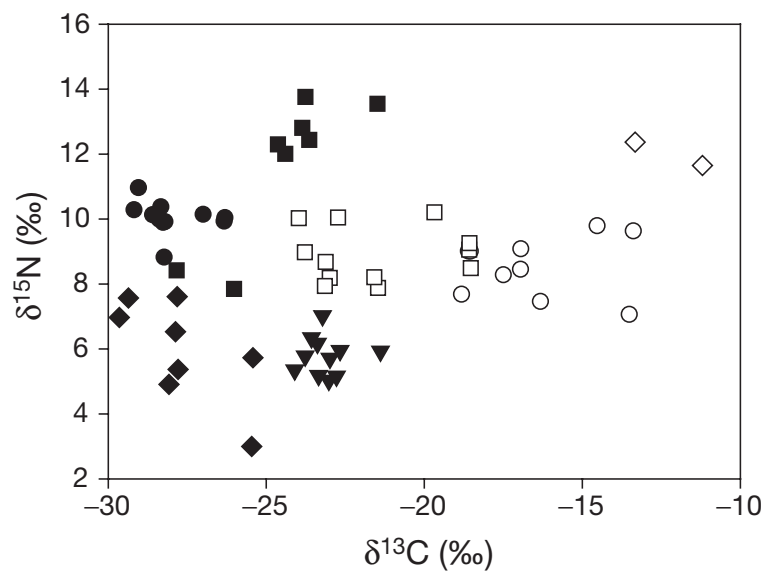

Fig. 5. $\delta^{13} \mathrm{C}$ versus $\delta^{15} \mathrm{~N}$ of potential food sources: microphytobenthos (O), Scirpus triqueter $(\bullet)$, surface sediment $(\mathbf{\nabla})$, suspended particulate organic matter (POM) in the channel ( $\square$ ), river POM $(\boldsymbol{\square})$, riparian vegetation $(\diamond)$ and macroalgae Enteromorpha compressa $(\diamond)$ 
Thus, dual isotope analysis enabled us to distinguish more clearly between these 2 sources.

Microphytobenthos (mainly benthic diatoms) had the most enriched $\delta^{13} \mathrm{C}$ values among the potential food sources, showing a relatively wide range of -18.8 to $-13.4 \%$ and a mean of $-16.5 \pm 2.1 \%$ (Tukey's HSDtest, $\mathrm{p}<0.05$; Fig. 5). Their $\delta^{15} \mathrm{~N}$ values varied between 7.1 and $9.8 \%$, with a mean of $8.7 \pm 1.0 \%$. These values for microphytobenthos are consistent with the ranges typical of microphytobenthos in the literature (Couch 1989, Créach et al. 1997, Riera et al. 1999, Wainright et al. 2000, Kang et al. 2006).

Isotopic signatures of SOM were located between the potential sources of organic matter, ranging from -24.0 to $-18.5 \%$ o (mean $-22.1 \pm 2.0 \%$ ) and from 7.9 to $10.2 \%$ (mean $8.9 \pm 0.8 \%$ o) for $\delta^{13} \mathrm{C}$ and $\delta^{15} \mathrm{~N}$, respectively (Fig. 5). Macroalgae covered broad areas of the flat before the Scirpus triqueter shoots appeared, and then disappeared when $S$. triqueter shoot growth was initiated. Thus, repeated sampling for macroalgae was not continued. The mean $\delta^{13} \mathrm{C}$ and $\delta^{15} \mathrm{~N}$ values of macroalgae for the sampling period were $-12.3 \pm 1.4$ and $12.0 \pm 0.5 \%$, respectively.

\section{Isotopic signatures of macrozoobenthic invertebrates}

Monthly isotopic data for macrobenthic invertebrates displayed statistically significant changes in the $\delta^{13} \mathrm{C}$ values in their tissues (Fig. 6). However, these changes were not related to the seasonal change in Scirpus triqueter biomass and did not show any marked trend with season. Furthermore, the $\delta^{13} \mathrm{C}$ ranges of each species were very small, and the coefficient of variation was $<10 \%$ for all the species analyzed (Fig. 6).

Overall, macrobenthic invertebrate species exhibited a wide range of values, between -26.4 and $-13.2 \%$ for $\delta^{13} \mathrm{C}$ and between 7.9 and $13.9 \%$ for $\delta^{15} \mathrm{~N}$ (Fig. 7). Their $\delta^{13} \mathrm{C}$ signatures are found within the range of potential food sources. Except for 2 bivalve species, the $\delta^{13} \mathrm{C}$ signatures of 5 invertebrate species were grouped in, and close to, the range of microphytobenthos, being 9 to $12 \%$ higher than those of Scirpus triqueter. Of the polychaetes, the nereid worm Hediste japonica had a wider $\delta^{13} \mathrm{C}$ range of -20.4 to $-14.3 \%$, with a mean of $-17.0 \pm$ $1.7 \%$, slightly more positive (Tukey HSD-test, $\mathrm{p}<0.05$ ) than the mean of $-19.0 \pm 0.8 \%$ (range $=-19.7$ to $-17.4 \%$ ) for the capitellid worm Heteromastus filiformis. ${ }^{13} \mathrm{C}$-enriched values, as shown by $H$. japonica, were found in the gastropod Angustassiminea castanea $($ range $=-17.5$ to $-13.2 \%$, mean $=-16.0 \pm 1.5 \%$ ), the crab Ilyoplax pusilla (range $=-17.1$ to $-14.3 \%$, mean $=$ $-15.6 \pm 1.0 \%$ ) and the isopod Paranthura sp. (range $=$ -17.9 to $-14.8 \%$, mean $=-16.5 \pm 1.3 \%$ o). The $\delta^{15} \mathrm{~N}$

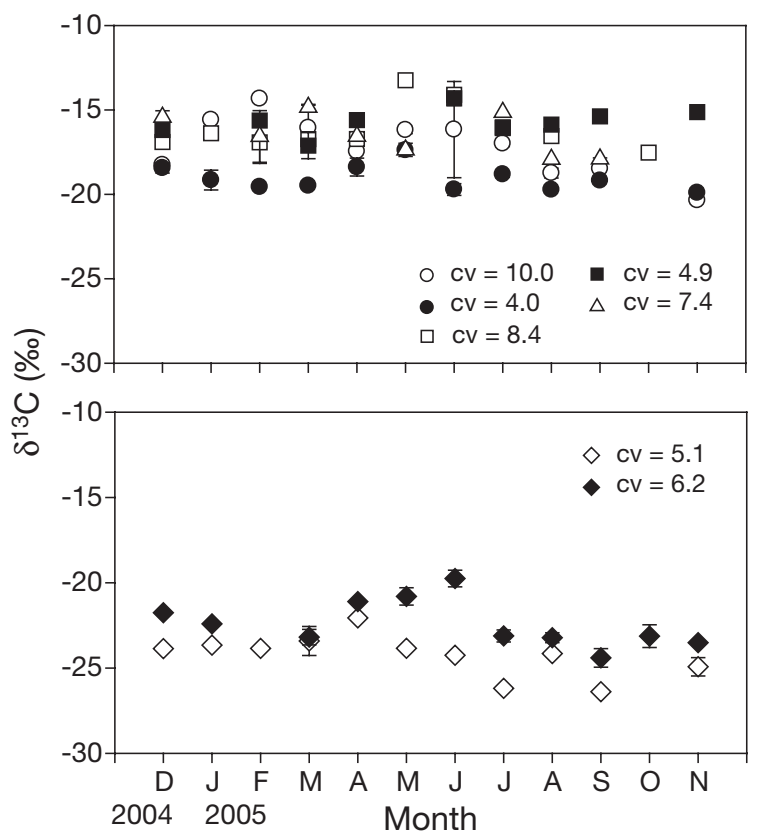

Fig. 6. Monthly variation of $\delta^{13} \mathrm{C}$ values of surface grazers and deposit feeders (O: Hediste japonica; •: Heteromastus filiformis; $\square:$ Angustassiminea castanea; $\mathbf{\square}$ : Ilyoplax pusilla; $\Delta$ : Paranthura sp.) and suspension-feeding bivalves $(\diamond:$ Laternula marilina; : Corbicula sp.). Coefficients of variation $(\mathrm{cv})=\mathrm{SD} /$ mean $\times 100$

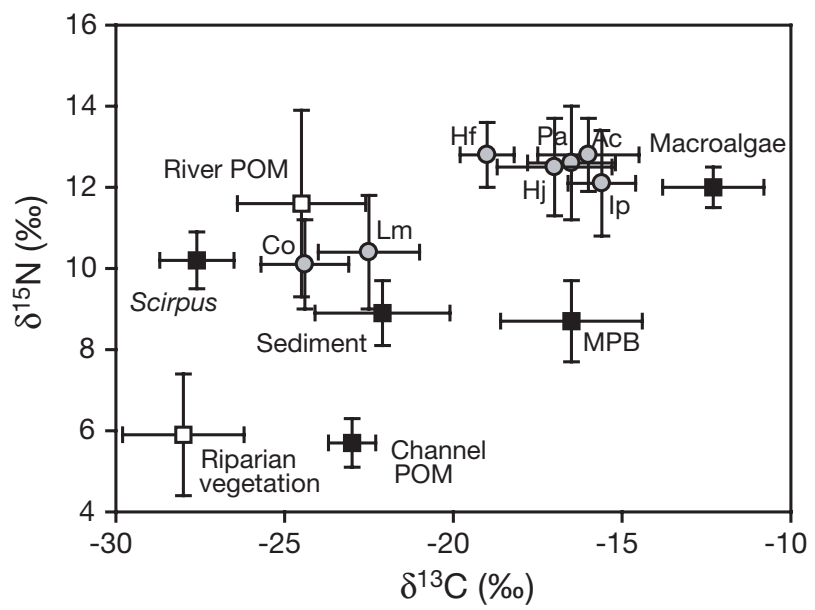

Fig. 7. Dual isotope plot of $\delta^{13} \mathrm{C}$ and $\delta^{15} \mathrm{~N}$ of macroinvertebrates and their food sources in the Scirpus triqueter bed of the Nakdong River estuary. Gray circles indicate consumers (Hj: Hediste japonica; Hf: Heteromastus filiformis; Ac: Angustassiminea castanea; Ip: Ilyoplax pusilla; Pa: Paranthura sp.; Lm: Laternula marilina; Co: Corbicula sp.) and squares indicate potential food sources (white: terrestrial; black: coastal marine). MPB: microphytobenthos; POM: particulate organic matter

values of these 5 species were within the same range, from 9.6 to $13.9 \%$, with mean values of $12.6 \pm 1.0,12.8 \pm$ $0.8,12.8 \pm 0.9,12.1 \pm 1.3$ and $12.6 \pm 1.4 \%$, respectively ( $p=0.149$ ), being generally 3 to $4 \%$ higher than those of microphytobenthos. 
The most negative $\delta^{13} \mathrm{C}$ values were found in 2 bivalve species, Corbicula sp. (range $=-26.4$ to $-22.1 \%$, mean $=-24.4 \pm 1.3 \%$ ) and Laternula marilina (range $=-24.4$ to $-19.8 \%$, mean $=-22.5 \pm 1.5 \%$ ) . Tukey's HSD-test showed that the mean $\delta^{13} \mathrm{C}$ value of the former was slightly lower than that of the latter $(\mathrm{p}<$ 0.05). The $\delta^{15} \mathrm{~N}$ values of these 2 bivalves were within the same range, from 8.6 to $12.5 \%$, with means of $10.4 \pm 1.4$ and $10.1 \pm 1.1 \%$, respectively. Their $\delta^{15} \mathrm{~N}$ values were 2 to $3 \%$ lower than those of the other invertebrate taxa (Tukey's HSD-test, p < 0.05; Fig. 7).

\section{DISCUSSION}

\section{Seasonal dynamics of Scirpus triqueter, microphytobenthos and macrobenthos}

The marsh halophyte Scirpus triqueter population displayed a dramatic seasonal fluctuation, with a summer maximum in biomass and a winter disappearance (Fig. 2). Such seasonal dynamics have been observed by different authors for the Nakdong River estuary (Kim 2006). Along with the withering in fall of the above-ground stems, grazing activity of wintering waterfowl is known to play an important role in determining the seasonal decline of the $S$. triqueter population. Growth of this marsh plant occurs mostly between April and September, and tubers are formed at the end of the growing season (September and October). Environmental factors that affect the survival and growth of $S$. triqueter include salinity, tuber density, sediment type and tidal regime (Deegan et al. 2005, Kim 2006). The $S$. triqueter shoots are severed by waterfowl, such as geese and ducks, in October, and then most of them are swept away by the tides. Rapid reduction of the $S$. triqueter stem biomass is also partly due to grazing by ducks and mallards (Kim 2006). The waterfowl forage mainly on $S$. triqueter tubers (Doornbos et al. 1986); they graze $>60 \%$ of the tubers within the first $10 \mathrm{~d}$ of their arrival in mid-October. Over $80 \%$ of the tubers are distributed at a depth of 15 to $40 \mathrm{~cm}$ in the sediment, and most of the tuber biomass at all sediment depths disappears within a month after waterfowl begin to feed (Kim 2006).

Microphytobenthos biomass observed on a monthly basis during this study exhibited a uni-modal peak in summer (Fig. 3). Similar seasonal variability was also observed at the bare intertidal flat in neighboring geographical regions, such as Kwangyang Bay (Kang et al. 2006) and the Seto Inland Sea (Montani et al. 2003). These authors concluded that high primary production of microphytobenthos in summer is related to high irradiance, temperature and nutrient input through the river systems. An accumulation of microphytobenthos biomass is known to be associated with the high photosynthetic activity under conditions of high illumination (Médéler et al. 2005). Limitation for the microphytobenthos biomass on the marsh surface due to shading by macrophytes was expected (Wainright et al. 2000). However, there was no significant difference in the microphytobenthos biomass between the studied marsh site and the adjacent bare tidal flat site; furthermore, its seasonality exhibited a strikingly similar pattern at both sites, suggesting that the shading effect on the microphytobenthos biomass is not great in this marsh system. In addition, the marsh can be treated as an enormous kinetic energy-absorbing system (Yang 1998). Therefore, the existence of the marsh macrophytes, within our studied marsh bed, limits the mobility of surface sediments and the resuspension of microphytobenthos. The compositional pattern of algal pigment in the sediments was consistent in both the Scirpus triqueter marsh bed and the bare mudflat, showing the concurrent dominance of fucoxanthin and chl $C$, marker pigments for diatoms (data not shown). Although high abundances of blue-green algae, euglenoids and green algae were expected (Sullivan \& Currin 2000), their marker pigments (chl b, lutein and zeaxanthin) were detected in much smaller proportions. The most abundant component of the microphytobenthos in this marsh sediment was identified to be motile pinnate diatoms, e.g. the genera Navicula and Amphora (E. J. Choy unpubl. data).

The macrobenthic assemblage in the Scirpus triqueter marsh bed of the Nakdong River estuary displayed relatively lower faunal biodiversity than has been documented for other nearshore and shallow brackish habitats on the Korean peninsula (Koh 2001). Almost all the collected species are common and frequently abundant inhabitants of the Korean coastal wetlands. Despite the relatively low diversity, monthly total abundance of macrozoobenthos corresponds to the range commonly recorded in the Korean coastal wetlands due to the predominance of a few taxa. This community also includes seasonally abundant insect larvae due to salinity decreases.

The densities of most of the species showed irregular fluctuations, while a few species (e.g. the nereid polychaete Hediste japonica and the bivalve Laternula marilina) had a pronounced seasonal periodicity, with absence in winter and early spring (Table 2). Such irregular abundances in the former invertebrate assemblages are likely to be supported by opportunistic characteristics of these species exposed to the environmental instability of estuarine habitats (Silva et al. 2006), such as those of the Nakdong River estuary, where fresh water is irregularly discharged through the barrage (Jang \& Kim 2006). In contrast, the maximum densities of $H$. japonica and L. marilina, which 
occurred in late spring to summer, coincided with an increase in the Scirpus triqueter biomass. The available information on the reproductive biology and life history of these species indicates that the observed seasonal fluctuation in their density is expected to be mainly a result of their life cycle. For example, the largest number of mature adults of $H$. japonica participates in reproductive swarming from December to February (Sato 1999). Similarly, the recruitment of L. marilina is greatest in April and their growth continues until August in Kwangyang Bay adjacent to the Nakdong River estuary (Kang et al. 2006). A mass of $L$. marilina spawns in summer (August and September). Most of the individuals die off immediately after spawning, so density dropped abruptly after September. Therefore, the low densities of these 2 species during winter and early spring in this study are probably due to high mortality just after spawning, as these animals have life spans of $<1 \mathrm{yr}$ and die at the end of the reproductive period.

\section{Source and isotopic composition of suspended POM}

An inconsistency in isotopic composition between the channel POM and other potential sources (e.g. Scirpus triqueter leaves, river POM and microphytobenthos) probably indicates little contribution of other sources to the POM pool introduced into the marsh bed (Figs. 4 \& 5). The channel POM had intermediate $\delta^{13} \mathrm{C}$ values (mean $=-23.0 \pm 0.7 \%$ ) between those of the $S$. triqueter and microphytobenthos, which would be expected if these sources contributed equally to the POM. However, a dual isotope plot of $\delta^{13} \mathrm{C}$ and $\delta^{15} \mathrm{~N}$ indicates that the channel POM is composed largely of ${ }^{15} \mathrm{~N}$-depleted sources rather than multiple sources. The $\delta^{13} \mathrm{C}$ values of the channel POM in this study were consistent with the range ( -23.9 to $-21.5 \%$ ) previously found for phytoplankton in the salt marsh and in mangrove creeks (Dehairs et al. 2000, Wainright et al. 2000). This suggests that phytoplankton is the most probable candidate to account for the intermediate $\delta^{13} \mathrm{C}$ and low $\delta^{15} \mathrm{~N}$ values.

Riparian vegetation showed $\delta^{15} \mathrm{~N}$ values similar to, but more negative than, the channel POM, indicating independence between them. A wide gap in the isotopic composition between the river POM and riparian vegetation indicates a low connectivity between organic matters derived from riparian vegetation and the river POM pool, and further confirms little contribution of terrestrial organic matter to the estuarine POM pool. The river POM showed $\delta^{13} \mathrm{C}$ values similar to the channel POM, but much higher $\delta^{15} \mathrm{~N}$ values, precluding the importance of the river POM to the channel POM pool. It is well known that anthropogenic dis- solved inorganic nitrogen is significantly ${ }^{15} \mathrm{~N}$-enriched, and this enrichment is reflected in higher $\delta^{15} \mathrm{~N}$ signatures in primary producers and animals (Macko \& Ostrom 1994, McClelland et al. 1997). Therefore, the higher $\delta^{15} \mathrm{~N}$ signatures in the river POM could be indicative of a high availability of ${ }^{15} \mathrm{~N}$-enriched inorganic nitrogen of domestic and industrial origin in the hypereutrophic Nakdong River system (Kim et al. 2000).

The important role of phytoplankton to the channel POM pool may be explained by several chemical markers of POM determined concurrently during the study period (authors' unpubl. data). The ratio of particulate organic carbon to $\mathrm{chl}$ a $(\mathrm{C}: \mathrm{chl} a)$ was generally 150 or less and $\mathrm{C}$ : $\mathrm{N}$ mass ratios were $6.8 \pm 1.3$. According to previous studies, C:chl $a<100$ (Zeitzschel 1970) or $<200$ (Cifuentes et al. 1988) and C:N around 6 or 8 (Cifuentes et al. 1988) have been known to be characteristic of a predominance of newly produced phytoplankton in POM. The C:N values for stem and tuber (including root) of Scirpus triqueter were $45.5 \pm 16.3$ and $39.3 \pm 5.2$, respectively, during the study period, indicating a minor contribution of this marsh-derived detritus to the POM pool. Therefore, along with the isotopic composition, the C:chl $a<200$ and low C:N values of the channel POM allow us to speculate that there is a dominance of phytoplankton in the estuarine POM pool. Although it is difficult to distinguish between phytoplankton and microphytobenthos on the basis of these ratios, it should be noted that their $\delta^{13} \mathrm{C}$ and $\delta^{15} \mathrm{~N}$ values were clearly separated (discussed below).

\section{Utilization of algal source by macroinvertebrates}

The $\delta^{13} \mathrm{C}$ and $\delta^{15} \mathrm{~N}$ values were clearly differentiated into 2 invertebrate categories (Fig. 7). Therefore, the 7 dominant invertebrates in the marsh habitat clustered independently of their feeding guilds, indicating a dominant contribution of 2 ultimate sources of organic matter to their diets. One group, including surface grazers and deposit feeders such as polychaetes, gastropods, crab and isopods, had more enriched $\delta^{13} \mathrm{C}$ and $\delta^{15} \mathrm{~N}$ values than those of another group that included suspension-feeding bivalves. Furthermore, despite a great seasonal variability in the biomass of the clubrush marsh Scirpus triqueter, the expected seasonal change in the isotopic signatures of macroinvertebrates was not found.

A large gap in $\delta^{13} \mathrm{C}$ signature (on average 9 to $12 \%$; Fig. 7) between invertebrates of the former group and the club-rush marsh Scirpus triqueter reveals that ${ }^{13} \mathrm{C}$-enriched sources other than $S$. triqueter-derived carbon contribute mainly to their diets. Two deposit- 
Table 3. Distributions of feasible contributions (\%) of 4 food sources (Scirpus triqueter, river POM, channel POM and microphytobenthos [MPB]) to consumer production, as determined by 2 isotopes of $\delta^{13} \mathrm{C}$ and $\delta^{15} \mathrm{~N}$ (after correcting for trophic fractionation of about $1 \%$ o for $\delta^{13} \mathrm{C}$ and $3.4 \%$ for $\delta^{15} \mathrm{~N}$ ): see detailed procedures for calculation in Phillips \& Gregg (2003)

\begin{tabular}{|lcccc|}
\hline Consumer & $\begin{array}{c}\text { Scirpus } \\
\text { triqueter }\end{array}$ & $\begin{array}{c}\text { River } \\
\text { POM }\end{array}$ & $\begin{array}{c}\text { Channel } \\
\text { POM }\end{array}$ & MPB \\
\hline Hediste japonica & $0-2$ & $16-18$ & $0-1$ & $81-82$ \\
Heteromastus filiformis & $0-26$ & $5-36$ & $0-11$ & $54-68$ \\
Angustassiminea castanea & $0-6$ & $3-12$ & $0-3$ & $87-93$ \\
Ilyoplax pusilla & $0-1$ & $0-1$ & $0-1$ & $98-99$ \\
Paranthura sp. & 0 & $14-15$ & 0 & $85-86$ \\
Laternula marilina & $6-14$ & $4-12$ & $78-82$ & $0-4$ \\
Corbicula sp. & $3-42$ & $0-1$ & $56-67$ & $0-4$ \\
\hline
\end{tabular}

within anoxic sediments, not bacteriaderived carbon sources. Therefore, the slight difference in $\delta^{13} \mathrm{C}$ values between these 2 polychaete species probably reflects different degrees of selectivity depending on their feeding modes.

$\delta^{13} \mathrm{C}$ signatures of the gastropod Angustassiminea castanea, the crab Ilyoplax pusilla and the isopod Paranthura sp. were most enriched and overlapped with those of microphytobenthos. This provides supportive evidence for their exclusive use of organic matter derived from microphytobenthos. Their $\delta^{15} \mathrm{~N}$ values (12.8 \pm

feeding polychaetes, Hediste japonica and Heteromastus filiformis, had $\delta^{13} \mathrm{C}$ signatures intermediate between those of SOM and microphytobenthos, being 3 to $5 \%$ higher than those of SOM. This enrichment was much higher than the general trophic fractionation factor (within 1\%; Fry \& Sherr 1984). In the dual isotope plot (Fig. 7), marsh SOM is found in the area of the ranges in which a mixture of autochthonous and allochthonous sources is expected to exist. Therefore, the higher $\delta^{13} \mathrm{C}$ signatures, compared to those of SOM, suggest they feed selectively on microphytobenthos, which have the most enriched $\delta^{13} \mathrm{C}$ values encountered in this study. Their $\delta^{15} \mathrm{~N}$ values $(12.6 \pm 1.0$ and $12.8 \pm$ $0.8 \%$, respectively) were about $4 \%$ higher than those of microphytobenthos $(8.7 \pm 1.0 \%)$. This corresponds to the general trophic fractionation factor $(3.4 \pm 1.0 \%$; Minagawa \& Wada 1984, Owens 1987), confirming the above hypothesis. Indeed, linear mixing model calculations based on mass balance equations using $\delta^{13} \mathrm{C}$ and $\delta^{15} \mathrm{~N}$ signatures of 4 sources of organic matter showed that microphytobenthos constitute a major dietary component of $H$. japonica and $H$. filiformis (81 to 82 and 54 to $68 \%$, respectively; Table 3). Although not great, there was a significant difference in $\delta^{13} \mathrm{C}$ value and thus dependence upon microphytobenthos between 2 polychaetes: $H$. japonica having $\delta^{13} \mathrm{C}$ values closer to microphytobenthos than $H$. filiformis. Some of the nereids, such as $H$. japonica, despite their omnivorous feeding mode, show an opportunistic dietary choice for fresh algal diet produced from local sources (Hsieh et al. 2002). They are also known to be surfacefeeding omnivores that often move on the sediment surface to capture small prey (Reise 1985). The capitellid worm $H$. filiformis is a non-selective deposit feeder, often found in organically enriched sediments; they orient themselves in a head-down position below the surface of the sediment (Clough \& Lopez 1993). Clough \& Lopez (1993) showed that this worm utilizes both dissolved and particulate carbon sources stored
$0.8,12.8 \pm 0.9$ and $12.1 \pm 1.3 \%$, respectively) were 3.4 to $4.1 \%$ higher than those of microphytobenthos, also supporting this assimilation. Isotopic mixing model estimates also showed that microphytobenthos were definitely major dietary components for these species, with feasible contributions of 87 to 93,98 to 99 and 85 to $86 \%$, respectively (Table 3). Kurata et al. (2001) demonstrated that microalgae, such as phytoplankton and benthic diatoms, in deposited seston are the most important food sources for 2 species of assimineids (Assimininea japonica and Angustassiminea castanea) in salt marshes. A non-selective deposit-feeding gastropod, A. japonica, which is a similar assimineid species to A. castanea, feeds mainly on microphytobenthos at the estuarine marsh flat, where the availability of this source is high (Doi et al. 2005). By contrast, the crab I. pusilla scrapes organic material from the surface of sediment particles and feeds selectively on microphytobenthos, even in the marsh area, where the availability of this source is relatively low due to the decrease in algal productivity by shading of marsh plants. Details of the feeding habits of Paranthura sp. are not available in the literature. Although most isopods are scavengers and carnivores, and some are herbivores, deposit feeding is common (Barnes 1987). Alteration of epiphytic algal biomass by mesograzers (herbivores $<2.5 \mathrm{~cm}$ ), including crabs, amphipods, isopods and polychaete worms, is a well-known phenomenon in intertidal habitats (Ruesink 2000).

When considering the high availability of microphytobenthos in the Scirpus triqueter marsh bed (sediment chl a content is comparable to the neighboring bare intertidal flat; Fig. 3), their easy digestibility and their better food quality (e.g. Newell \& Langdon 1986), the consistency of carbon isotope values between deposit feeders and microphytobenthos within the $S$. triqueter bed in the Nakdong River estuary is not surprising. The minor nutritional role of $S$. triqueter to the marsh food web is also likely to be 
attributed to a lack of herbivores directly grazing on its stems or tubers, as well as the removal of $S$. triqueter stems by the tides, and elimination of the tubers by waterfowl foraging.

Two suspension-feeding bivalves, Laternula marilina and Corbicula sp., showed $\delta^{13} \mathrm{C}$ signatures of great similarity to those of the estuarine POM, and their $\delta^{15} \mathrm{~N}$ signatures $(10.4 \pm 1.4$ and $10.1 \pm 1.1 \%$, respectively) were about $4 \%$ higher relative to this source. Our data indicate that these bivalves use carbon and nitrogen derived from the suspended POM, which is introduced into the marsh bed through the tidal channel. Using the isotopic mixing model, it was also possible to determine a significant contribution of the channel POM to the bivalve diet, with feasible contributions of 78 to $82 \%$ for L. marilina and 56 to $67 \%$ for Corbicula sp. (Table 3). It is well known from different salt marsh habitats that resuspended microphytobenthos are an important food source for suspension-feeding bivalves (Page 1997, Riera et al. 1999). However, in the marsh habitat of the Nakdong River estuary, benthic microalgae are postulated to play a minor role as a food source for the suspension feeders. Absorption processes of tide- and wind-induced energy by the marsh is likely to explain this phenomenon as already discussed. The resuspension of microphytobenthos is expected to be inactive in the marsh system, due to the attenuation of kinetic energy and the sediment-trapping effect by leaves of the marsh plants (Yang 1998, also references therein). Our data suggest that limited resuspension of microphytobenthos probably resulted in the heterogeneity in carbon and nitrogen stable isotope values between the suspended POM and microphytobenthos. Although tidally induced resuspension events may occur after the disappearance of the marsh plants in fall, bivalves may become quiescent at low temperatures during winter (Newell 1979). Bearing the trophic fractionation factor of $3.4 \pm 1.0 \%$ in $\delta^{15} \mathrm{~N}$ in mind, $\delta^{15} \mathrm{~N}$ signatures of the bivalves $(10.4 \pm 1.4$ and $10.1 \pm 1.1 \%$, respectively, lower than $11.6 \pm 2.3 \%$ of the river POM) indicate that the river POM is not wholly absorbed by these species. Fresh river water discharge through the Nakdong River Barrier is concentrated during the summer monsoon period. This event lowers salinities in tidal channels to 0 psu for a few hours (Jang \& Kim 2006). Bivalves tend to close their shells to withstand the stress of low ambient salinities (Newell 1979). $\delta^{15} \mathrm{~N}$ values of the estuarine POM were consistent with those of the adjacent offshore phytoplankton (6.2 \pm $0.8 \%$; authors' unpubl. data). Accordingly, as speculated for the source and composition of the channel POM, the overall isotope dataset indicates that phytoplankton-derived organic matter is an important food source for suspension-feeding bivalves.
On the other hand, mixing model calculations suggested that 30 to $42 \%$ of the diet of Corbicula sp. is derived from Scirpus triqueter (Table 3). However, causes of the slight shift in $\delta^{13} \mathrm{C}$ values between these bivalve species are not fully explained in this study. This isotopic difference probably results from their slightly different feeding modes. Adults of Corbicula sp. have the association of anterior inhalant currents and pedal-feeding habits that employ the foot for food particle collection (Reid et al. 1992). Such a feeding habit is distinct from suspension-feeding and depositfeeding modes, involving the posterior inhalant siphon and ctenidial filtration.

\section{CONCLUSIONS}

We found no evidence that the Scirpus triqueter effect on the marsh food web was stronger in summer to fall, when its biomass varied from plentiful to scarce, than in the winter to spring period, when $S$. triqueter on the marsh flat was non-existent. Indeed, a large gap in the $\delta^{13} \mathrm{C}$ signature between $S$. triqueter and the marsh-dwelling macroinvertebrates was found throughout the year. The reasons for the minor utilization of this marsh plant by animals are possibly because benthic herbivores directly grazing on $S$. triqueter are absent and $S$. triqueter detritus is swept away by the tides after being severed by waterfowl. Stable isotope data indicate that river POM was not important in the dietary sources of macroinvertebrates in the $S$. triqueter marsh bed. These results coincided with a change in the oceanographic conditions from an estuarine- to an oceanic-dominated system since the construction of the Nakdong River Barrier in 1987 (Jang \& Kim 2006). Overall, the isotopic data show that, while benthic feeders used mainly organic matter derived from microphytobenthos, suspension-feeding bivalves utilized mostly suspended POM (composed largely of coastal phytoplankton), despite a slight shift in $\delta^{13} \mathrm{C}$ between bivalves. Our results support the previous idea that the feeding habit (i.e. feeding mode and food selectivity) of macrozoobenthos and the availability of particular food sources to non-selective feeders are essential stimulants to the estuarine food web (Doi et al. 2005). The trophic importance of microphytobenthos (largely benthic diatoms) and imported phytoplankton has been well established in salt marsh ecosystems that are composed of different types of vegetation (Sullivan \& Moncreiff 1990, Currin et al. 1995, Créach et al. 1997, Deegan \& Garritt 1997, Page 1997, Riera et al. 1999, Sullivan \& Currin 2000). As demonstrated by these previous studies of salt marshes containing different types of vegetation, our research supports the potential importance of locally produced 
benthic production, along with phytoplankton, to the nutrition of consumers even in an estuarine salt marsh (S. triqueter) habitat. The role of a high standing stock of $S$. triqueter as a trophic base for macroinvertebrates within this marsh system was determined to be negligible with the exception of Heteromastus filiformis and Corbicula sp. However, marsh detritus has been known to be of considerable importance to estuarine food webs (Currin et al. 1995, Stribling \& Cornwell 1997, Wainright et al. 2000). The fate of a large quantity of $S$. triqueter biomass transported to adjacent coastal areas in late fall and its role as a carbon source in coastal food webs remains to be assessed.

Acknowledgements. This project was supported by the Korean Ministry of Environment as 'The Eco-technopia 21 project' (Project No. 050010013). We are grateful for valuable comments by 3 anonymous referees. E.J.C. and H.J.P. were supported by scholarships from the Brain Korea 21 Project in 2006.

\section{LITERATURE CITED}

Barnes RD (1987) Invertebrate zoology, 5th edn. Saunders College Publishing, Philadelphia, PA

Chanton J, Lewis GG (2002) Examination of coupling between primary and secondary production in a riverdominated estuary: Apalachicola Bay, Florida, USA. Limnol Oceanogr 47:683-697

Cifuentes LA, Sharp JH, Fogel ML (1988) Stable carbon and nitrogen isotope biogeochemistry in the Delaware estuary. Limnol Oceanogr 33:1102-1115

Clough LM, Lopez GR (1993) Potential carbon sources for the head-down deposit-feeding polychaete Heteromastus filiformis. J Mar Res 51:595-616

Couch CA (1989) Carbon and nitrogen stable isotopes of meiobenthos and their food resources. Estuar Coast Shelf Sci 28:433-441

Créach V, Schrike MT, Bertru G, Mariotti A (1997) Stable isotopes and gut content analyses to determine feeding relationships in saltmarsh macroconsumers. Estuar Coast Shelf Sci 44:599-611

Currin CA, Newell SY, Paerl HW (1995) The role of standing dead Spartina alterniflora and benthic microalgae in salt marsh food webs: considerations based on multiple stable isotope analysis. Mar Ecol Prog Ser 121:99-116

Darnell RM (1961) Trophic spectrum of an estuarine community, based on studies of Lake Pontchatrain, Louisiana. Ecology 42:553-568

Deegan B, Harrington TJ, Dundon P (2005) Effects of salinity and inundation regime on growth and distribution of Schoenoplectus triqueter. Aquat Bot 81:199-211

Deegan LA, Garritt RH (1997) Evidence for spatial variability in estuarine food webs. Mar Ecol Prog Ser 147:31-47

Dehairs F, Rao GG, Chandra Mohan P, Raman AV, Marguillier S, Hellings L (2000) Tracing mangrove carbon in suspended matter and aquatic fauna of the GautamiGodavari Delta, Bay of Bengal (India). Hydrobiologia 431: 225-241

Doi H, Matsumasa M, Toya T, Satoh N, Mizota C, Maki Y, Kikuchi E (2005) Spatial shifts in food sources for macrozoobenthos in an estuarine ecosystem: carbon and nitro- gen stable isotope analyses. Estuar Coast Shelf Sci 64: 316-322

Doornbos G, Groenendijk AM, Jo YW (1986) Nakdong Estuary barrages and reclamation project: preliminary results of the botanical, macrozoobenthic and ornithological studies. Biol Conserv 38:115-142

Fry B, Sherr EB (1984) $\delta^{13} \mathrm{C}$ measurements as indicators of carbon flow in marine and freshwater ecosystems. Contrib Mar Sci 27:13-47

Haines EB (1976) Stable carbon isotope ratios in the biota, soils, and tidal water of a Georgia salt marsh. Estuar Coast Mar Sci 4:609-619

Hsieh HL, Chen CP, Chen YG, Yang HH (2002) Diversity of benthic organic matter flows through polychaetes and crabs in a mangrove estuary: $\delta^{13} \mathrm{C}$ and $\delta^{34} \mathrm{~S}$ signals. Mar Ecol Prog Ser 227:145-155

Jang ST, Kim KC (2006) Change of oceanographic environment in the Nakdong Estuary. 'The Sea'. J Korean Soc Oceanogr 11:11-20

Kang CK, Lee YO, Choy EJ, Shin JK, Seo IS, Hong JS (2006) Microphytobenthos seasonality determines growth and reproduction in intertidal bivalves. Mar Ecol Prog Ser 315: $113-127$

Kim GY (2006) Grazing impact of wintering waterfowl on growth dynamics of Schoenoplectus triqueter in the Nakdong River estuary. PhD thesis, Pusan National University, Busan

Kim HW, Hwang SJ, Joo GJ (2000) Zooplankton grazing on bacteria and phytoplankton in the regulated Nakdong River (Korea). J Plankton Res 22:1559-1577

Koh CH (2001) The Korean tidal flat: environment, biology and human. Seoul National University Press, Seoul

Kurata K, Minami H, Kikushi E (2001) Stable isotope analysis of food sources for salt marsh snails. Mar Ecol Prog Ser 223:167-177

Macko SA, Ostrom NE (1994) Pollution studies using stable isotopes. In: Lajtha K, Michener RH (eds) Stable isotopes in ecology and environmental science. Blackwell Scientific Publications, Oxford, p 45-62

Mann KH (1982) Ecology of coastal waters. University of California Press, Berkeley

McClelland JW, Valiela I, Michener RH (1997) Nitrogen isotope signatures in estuarine food webs: a record of increasing urbanization of coastal watersheds. Limnol Oceanogr 42:930-937

Médéler V, Barillé L, Rincé Y, Morançais M, Rosa P, Gaudin P (2005) Spatio-temporal changes in microphytobenthos structure analysed by pigment composition in a macrotidal flat (Bourgneuf Bay, France). Mar Ecol Prog Ser 297: 83-99

Michener RH, Schell DM (1994) Stable isotope ratios as tracers in marine aquatic food webs. In: Lajtha $\mathrm{K}$, Michener RH (eds) Stable isotopes in ecology and environmental science. Blackwell Scientific Publications, Oxford, p 138-157

Minagawa M, Wada E (1984) Stepwise enrichment of ${ }^{15} \mathrm{~N}$ along food chains: further evidence and the relation between $\delta^{15} \mathrm{~N}$ and animal age. Geochim Cosmochim Acta 48:1135-1140

Montani S, Magni P, Abe N (2003) Seasonal and interannual patterns of intertidal microphytobenthos in combination with laboratory and areal production estimates. Mar Ecol Prog Ser 249:79-91

Newell RC (1979) Biology of intertidal animals. Marine Ecological Surveys, Faversham

Newell RIE, Langdon (1986) Digestion and absorption of refractory carbon from the plant Spartina alterniflora by the oyster Crassostrea virginica. Mar Ecol Prog Ser 34:105-115 
Nixon SW (1980) Between coastal marshes and coastal waters - a review of twenty years of speculation and research on the role of salt marshes in estuarine productivity and water chemistry. In: Hamilton P, MacDonald K (eds) Estuarine and wetland processes. Plenum, New York, p 437-525

Odum EP (1980) The status of three ecosystem-level hypotheses regarding salt marsh estuaries: tidal subsidy, outwelling, and detritus-based food chain. In: Kennedy V (ed) Estuarine perspectives. Academic Press, New York, p 485-495

Owens NJP (1987) Natural variations in ${ }^{15} \mathrm{~N}$ in the marine environment. Adv Mar Biol 24:389-451

Page HM (1997) Importance of vascular plant and algal production to macro-invertebrate consumers in a southern California salt marsh. Estuar Coast Shelf Sci 45:823-834

Peterson BJ, Fry B (1987) Stable isotopes in ecosystem studies. Annu Rev Ecol Syst 18:293-320

Peterson BJ, Howard RW (1987) Sulfur, carbon, and nitrogen isotopes used to trace organic matter flow in the salt marsh estuaries of Sapelo Island, Georgia. Limnol Oceanogr 32: 1195-1213

Phillips DL, Gregg JW (2003) Source partitioning using stable isotopes: coping with too many sources. Oecologia 136: 261-269

Reid RGB, McMahon RF, Foighil DÓ, Finnigan R (1992) Anterior inhalant currents and pedal feeding in bivalves. Veliger 35:93-104

Reise K (1985) Tidal flat ecology: an experimental approach to species interactions. Springer-Verlag, Berlin

Riera P, Stal LJ, Nieuwenhuiz J, Richard P, Blanchard G, Gentil $F$ (1999) Determination of food sources for benthic invertebrates in a salt marsh (Aiguillon Bay, France) by carbon and nitrogen stable isotopes: importance of locally produced sources. Mar Ecol Prog Ser 187:301-307

Ruesink JL (2000) Intertidal mesograzers in field microcosms: linking laboratory feeding rates to community dynamics. J Exp Mar Biol Ecol 248:163-176

Sato M (1999) Divergence of reproductive and developmental

Editorial responsibility: Howard Browman (Associate Editorin-Chief), Storebø, Norway characteristics in Hediste (Polychaeta: Nereididae). Hydrobiologia 402:129-143

Silva G, Costa JL, Almeida PR, Costa MJ (2006) Structure and dynamics of a benthic invertebrate community in an intertidal area of the Tagus estuary, western Portugal: a six year data series. Hydrobiologia 555:115-128

Stribling JM, Cornwell JC (1997) Identification of important primary producers in a Chesapeake Bay tidal creek system using stable isotopes of carbon and sulfur. Estuaries 20:77-85

Sullivan MJ, Currin CA (2000) Community structure and functional dynamics of benthic microalgae in salt marshes. In: Weinstein MP, Kreeger DA (eds) Concepts and controversies in tidal marsh ecology. Kluwer Academic Publishers, Dordrecht, p 81-106

Sullivan MJ, Moncreiff CJ (1990) Edaphic algae are an important component of salt marsh food webs: evidence from multiple stable isotope analyses. Mar Ecol Prog Ser 62: 149-159

Teal JM (1962) Energy flow in the salt marsh ecosystem of Georgia. Ecology 43:614-624

Wainright SC, Weinstein MP, Able KW, Currin CA (2000) Relative importance of benthic microalgae, phytoplankton and the detritus of smooth cordgrass Spartina alterniflora and the common reed Phargmites australis to brackishmarsh food webs. Mar Ecol Prog Ser 200:77-91

Yang SL (1998) The role of Scirpus marsh in attenuation of hydrodynamics and retention of fine sediment in the Yangtze Estuary. Estuar Coast Shelf Sci 47:227-233

Yang SR, Song HS, Moon CH, Kwon KY, Yang HS (2001) Changes in marine environment and primary production due to freshwater input in the Nakdong Estuary. Algae 16: 165-177

Yokoyama H, Ishihi Y (2003) Feeding of the bivalve Theora lubrica on benthic microalgae: isotopic evidence. Mar Ecol Prog Ser 255:303-309

Zeitzschel B (1970) The quality, composition and distribution of suspended particulate matter in the Gulf of California. Mar Biol 7:305-318

Submitted: June 12, 2006; Accepted: August 23, 2006

Proofs received from author(s): March 6, 2007 